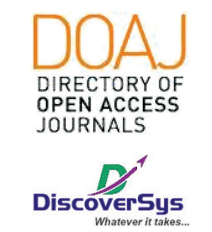

Published by DiscoverSys

\section{Efek latihan kesamaptaan terhadap kadar D-Dimer pada anggota militer Kodam I Bukit Barisan}

\author{
R. Prathama Wiradharma, ${ }^{1 *}$ Nizam Zikri Akbar, ${ }^{2}$ Adi Koesoema Aman ${ }^{1}$
}

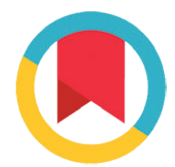

CrossMark

\title{
ABSTRACT
}

Background: Several reports and experiences show that when doing heavy exercise often occur complaints which direct the diagnosis towards Venous Thrombo-Embolism (VTE) in the form of painful and swollen feet. This was due to hypercoagulation and resulted in VTE. The D-dimer level is a measure of clot formation and lysis resulting from the breakdown of fibrinogen and fibrin during fibrinolysis. Therefore this study aimed to see an increase in D-Dimer which is a marker of increased fibrinolysis. Method: This study took a sample of blood from 30 soldiers who were declared healthy. The sample was checked for D-Dimer 1 hour before and after the test. The physical readiness test is a standard for assessing the readiness of soldiers in carrying out tasks. The sample was evaluated whether there was an increase after the test. Examination using Coatron machine with the Immuno Turbidimetric Assay method. Result: 30 people are men with an average age of 19-22 years. D-Dimer showed a significant difference with a mean of $92.83 \pm 49.62$ SD before the test and after the test found a mean of $127.53 \pm 57.75$ SD with $p=0.001(p<0.05)$.

Conclusion: The increase in D-Dimer shows an increase in blood coagulation processes and fibrinolysis and can occur in individuals who often carry out heavy activities. D-Dimer and Dopler ultrasound screening should be carried out on a periodic check before carrying out the physical readiness test.

Keyword: Venous Thrombo-Embolism, D-Dimer, physical readiness test Cite This Article: Wiradharma, R.P., Akbar, N.Z., Aman, A.K. 2019. Efek latihan kesamaptaan terhadap kadar D-Dimer pada anggota militer Kodam I Bukit Barisan. Intisari Sains Medis 10(2): 393-397. D0I: 10.15562/ism.v10i2.363

ABSTRAK

Latar Belakang: Beberapa laporan dan pengalaman yang menunjukkan bahwa pada pelaksanaan kegiatan fisik berat sering terjadi keluhan yang mengarahkan diagnosa ke arah Venous Thrombo Embolism (VTE) berupa kaki nyeri dan bengkak. Diduga hal ini disebabkan adanya hiperkoagulasi dan mengakibatkan VTE pada orang tersebut. Tingkat D-dimer adalah ukuran pembentukan gumpalan dan lisis yang dihasilkan dari pemecahan fibrinogen dan fibrin selama fibrinolisis. Maka dari itu penelitian ini ditujukan untuk melihat adanya peningkatan D-Dimer yang merupakan penanda meningkatnya proses koagulasi darah dan fibrinolisis.

Metode: Penelitian ini mengambil sample darah dari prajurit TNI yang dinyatakan sehat sebanyak 30 orang. Sample diperiksa untuk D-Dimer 1 jam sebelum dan sesudah pelaksanaan tes kesamaptaan.
Tes kesamaptaan merupakan standar baku untuk menilai kesiapan prajurit dalam melaksanakan tugas. Sampel dilihat apakah ada peningkatan setelah pelaksanaan tes. Pemeriksaan menggunakan alat Coatron dengan metode Immuno Turbidimetric Assay.

Hasil: 30 orang merupakan laki-laki dengan rata-rata umur 1922 tahun. D-Dimer menunjukan perbedaan signifikan dengan mean $92,83 \pm 49,62$ SD sebelum tes dan setelah tes kesamaptaan didapatkan mean $127,53 \pm 57,75$ SD dan $p=0.001(p<0.05)$.

Simpulan: Peningkatan D-Dimer menunjukkan terjadinya peningkatan proses koagulasi darah dan fibrinolisis dan dapat terjadi pada individu yang sering melaksanakan aktivitas berat. Perlu dilaksanakan skrining D-Dimer dan USG Dopler pada pemeriksaan berkala sebelum melaksanakan tes kesamaptaan.
${ }^{2}$ Departemen Kardiologi dan Kedokteran Vaskular, Fakultas Kedokteran Universitas, Sumatera Utara / RSUP H. Adam Malik, Medan, Indonesia

*Korespondensi:

R. Prathama Wiradharma;

Departemen Patologi Klinik, Fakultas Kedokteran, Universitas Sumatera Utara/RSUP H. Adam Malik, Medan, Indonesia,

prathamawira@gmail.com

Diterima: 13-11-2018

Disetujui: 04-02-2019

Diterbitkan: 01-08-2019
Kata Kunci : Venous Thrombo Embolism, D-Dimer, tes kesamaptaan

Cite Pasal Ini: Wiradharma, R.P., Akbar, N.Z., Aman, A.K. 2019. Efek latihan kesamaptaan terhadap kadar D-Dimer pada anggota militer Kodam I Bukit Barisan. Intisari Sains Medis 10(2): 393-397. D0I: 10.15562/ism.v10i2.363

\section{PENDAHULUAN}

Tingkat D-dimer adalah ukuran pembentukan gumpalan dan lisis yang dihasilkan dari pemecahan fibrinogen dan fibrin selama fibrinolisis. Uji D-dimer kuantitatif laboratorium pusat pada awalnya didasarkan pada teknologi enzyme-linked immunosorbent assay (ELISA) namun baru-baru ini telah disesuaikan dengan alat analisa koagulasi dan analisa kimia klinis, dengan titik akhir berdasarkan imunofluorecens, immunoturbidimetry, atau chemiluminescence. Pemeriksaan D Dimer banyak digunakan sebagai indikator adanya hiperkoagulabilitas darah, 
terutama aliran darah vena atau Venous Thrombo Embolism (VTE). ${ }^{1}$

Menurut White Venous Thromboembolism (VTE) atau trombo emboli vena adalah kondisi yang melemahkan dan berpotensi fatal. Terjadinya VTE berasal dari pembentukan gumpalan pada sirkulasi vena dan timbul sebagai thrombosis. ${ }^{2}$ Terdapat penilaian kritis terhadap triad Virchow (sekitar tahun 1854) mengingat pengetahuan kontemporer mengenai VTE menunjukkan bahwa orang-orang yang aktif secara fisik dan sangat mungkin terutama mereka yang mengejar latihan kardiovaskular dapat terpapar beberapa faktor risiko trombogenik yang berpotensi menjadi VTE. ${ }^{3}$

Insidens VTE di Eropa dan Amerika Serikat kurang lebih 50 per 100.000 populasi/tahun. Angka kejadian VTE meningkat sesuai umur, sekitar 1 per 10.000 - 20.000 populasi pada umur di bawah 15 tahun hingga 1 per 1000 populasi pada usia di atas 70 tahun. Insidens VTE pada ras Asia dan Hispanik dilaporkan lebih rendah dibandingkan pada ras Kaukasia, Afrika-Amerika Latin, dan Asia Pasifik. Tidak ada perbedaan insidens yang signifikan antara pria dan wanita. ${ }^{4}$

Tes kesamaptaan adalah merupakan suatu instrumen untuk menilai kesegaran jasmani dan kesiapan prajurit untuk bekerja maupun bertempur. Tes ini berpedoman pada penelitian yang dilakukan oleh Kenneth H Cooper dari United States Air Force (USAF), dimana penilaiannya berdasarkan katagori pencapaian $\mathrm{VO}_{2}$ max. Sejalan dengan meningkatnya teknologi dan pengembangan penelitian Cooper maka tes lari sejauh-jauhnya dalam 12 menit berubah menjadi lari 3200 meter yang kemudian digunakan sebagai alat untuk mengukur tingkat kebugaran cardiovaskular militer Amerika Serikat dan selanjutnya digunakan oleh Angkatan Bersenjata negara-negara lain termasuk oleh TNI. ${ }^{5}$

Beberapa studi (penelitian) telah dilakukan dengan hasil meningkatnya salah satu biomarker klinik yang menunjang diagnosa VTE, disamping menilai dengan skoring yaitu dengan menilai peningkatan D-Dimer. Kevin dkk pada tahun 2014 melaporkan bahwa terjadi peningkatan signifikan D-Dimer, setelah melaksanakan tes kesegaran jasmani pada 14 orang anggota militer angkatan laut Amerika Serikat. ${ }^{6}$

Aktivitas fibrinolitik meningkat saat seseorang melaksanakan latihan atau olahraga yang termasuk kategori berat, guna menyeimbangkan status hiperkoagulabilitas sementara ketika berolahraga dan faktor-faktor trombogenik lain seperti terhambatnya sirkulasi dan kerusakan vaskuler. ${ }^{7}$ Apabila aktivitas fibrinolitik meningkat maka akan diikuti dengan kadar D-Dimer yang meningkat sebagai pembentukan gumpalan dan lisis yang dihasilkan dari pemecahan fibrinogen dan fibrin selama fibrinolisis. Lalu selama 3-4 jam setelah pelaksanaan latihan, kadar D-Dimer akan turun menjadi kadar normal, dikarenakan Half-Life D-Dimer. ${ }^{8}$ Peningkatan D-Dimer ini penting karena pada kejadian VTE kadarnya akan meningkat. ${ }^{9}$

Secara umum dapat diterima bahwa kegiatan seperti olahraga ringan dan sedang sepertinya menurunkan resiko trombosis vena, dan tidak dapat dipungkiri keuntungannya lebih banyak daripada tidak melaksanakan olahraga sama sekali. $^{10}$ Tetapi resiko VTE yang berhubungan dengan kegiatan berat yang ekstrim yang dalam hal ini kegiatan kesamaptaan, perlu diperhatikan lebih, terutama karena banyaknya literatur yang menyatakan bagaimana intensitas latihan mempengaruhi resiko kejadian thrombosis. ${ }^{11}$

Dengan adanya biomarker D-Dimer yang dilaporkan mempunyai manfaat yang tinggi dalam biomarker VTE maka akan sangat menarik apabila diteliti dalam kaitannya dengan kejadian VTE pada olahraga. Dengan bermacamnya latihan pada sektor sipil yang mempunyai sifat intensitas tinggi, repetisi tinggi, minimal resisten dan minimal istirahat tahun-tahun belakangan ini, tak dapat dielakkan lagi, klinisi-klinisi menemukan gejala dan keluhan yang sama akibat melaksanakan kegitan tersebut. ${ }^{12}$

Penelitian ini bertujuan untuk melihat apakah ada peningkatan D-Dimer dalam pelaksanaan kegiatan kesamaptaan prajurit TNI-AD dan menjadikan pedoman apabila terjadi keluhan dan gejala yang berhubungan dengan VTE, klinisi dapat memilah pemeriksaan yang akan di ajukan sebagai penunjang agar lebih mudah diakses dengan biaya yang lebih murah dan lebih spesifik untuk VTE, sehingga dapat digunakan pada fasilitas yang sederhana tanpa mengurangi akurasinya dan menyakiti serta merugikan pasien.

\section{METODE}

Penelitian dilakukan di Batalyon Raider 100 KODAM I Bukit Barisan dan Departemen Patologi Klinik Fakultas Kedokteran Universitas Sumatera Utara/RSUP Haji Adam Malik Medan bekerja sama dengan Departemen Kardiologi dan Kedokteran Vaskular Fakultas Kedokteran Universitas Sumatera Utara. Penelitian ini dilaksanakan dengan rancangan penelitian cohort. Penelitian dilakukan pada bulan Februari 2018 sampai dengan Maret 2018. Subyek penelitian adalah prajurit TNI AD yang telah dinyatakan sehat dan mempunyai jadwal latihan aerobik sekurang-kurangnya 30 menit, dan lebih dari tiga kali seminggu di Batalyon Raider 100 Binjai. Pemeriksaan D-Dimer dilaksanakan 1 jam sebelum melaksanakan tes kesamaptaan dan 1 jam setelah melaksanakan tes. Subyek penelitian adalah 30 prajurit yang dimana dijumpai sebanyak 
29 orang (99\%) mengalami peningkatan kadar D-Dimer 1 jam setelah melaksanakan tes dan 1 orang (1\%) tidak mengalami peningkatan kadar D-Dimer. Pemeriksaan D-Dimer menggunakan sampel darah plasma sitrat yang diperiksa dengan menggunakan alat Coatron A4, alat ini menggunakan metode immune turbidimetric assay.

Hasil penelitian dianalisa secara statistik dengan menggunakan software SPSS (Statistical Package for Social Sciences, Chicago, IL, USA) untuk Windows. Gambaran karakteristik pada subjek penelitian disajikan dalam bentuk tabulasi dan dideskripsikan. Untuk menganalisa peningkatan D-Dimer menggunakan uji Wilcoxon Sign Rank Test.

\section{HASIL}

Penelitian ini menggunakan sample terkumpul sesuai dengan kriteria inklusi pada penelitian ini sebanyak 30 prajurit yang berdomisili di Batalyon 100 Raider Kodam I Bukit Barisan Binjai.

Setelah dilakukan anamnesa, pemeriksaan fisik dan peninjauan riwayat kesehatan peserta, semua peserta tidak merokok, tidak pernah mengeluh keluhan VTE, tidak pernah mengkonsumsi obatobatan dan tidak mempunyai riwayat penyakit terdahulu yang mempengaruhi penelitian ini.

Pada tabel didapatkan Median (MinimumMaksimum) D-Dimer sebelum tes adalah

Tabel 1 Karakteristik Peserta $(\mathbf{n}=\mathbf{3 0})$

\begin{tabular}{|c|c|c|c|c|}
\hline \multirow{2}{*}{$\begin{array}{l}\text { Variabel } \\
\text { Jenis kelamin }\end{array}$} & & \multicolumn{3}{|c|}{$\begin{array}{c}\text { Hasil } \\
\text { (Rata-rata } \pm \text { SB)/ N(\%) }\end{array}$} \\
\hline & \multicolumn{4}{|c|}{ Jenis kelamin } \\
\hline \multicolumn{2}{|l|}{ Laki-laki } & \multicolumn{3}{|c|}{$30(100)$} \\
\hline \multicolumn{2}{|l|}{ Perempuan } & \multicolumn{3}{|c|}{$0(0)$} \\
\hline \multicolumn{2}{|l|}{ Umur (Tahun) } & \multicolumn{3}{|c|}{$20,7 \pm 0,89$} \\
\hline \multicolumn{5}{|c|}{ Tekanan Darah (mmHg) } \\
\hline \multicolumn{2}{|l|}{ Sistolik } & \multicolumn{3}{|c|}{$117,87 \pm 7,9$} \\
\hline \multicolumn{2}{|l|}{ Diastolik } & \multicolumn{3}{|c|}{$65,1 \pm 6,18$} \\
\hline \multicolumn{2}{|l|}{ Nadi (kali/menit) } & \multicolumn{3}{|c|}{$77,3 \pm 3,09$} \\
\hline \multicolumn{2}{|c|}{ Respiration rate (kali/menit) } & \multicolumn{3}{|c|}{$23,2 \pm 1,61$} \\
\hline \multicolumn{2}{|l|}{ Berat badan (kg) } & \multicolumn{3}{|c|}{$62,6 \pm 3,9$} \\
\hline \multicolumn{2}{|l|}{ Tinggi badan $(\mathrm{cm})$} & \multicolumn{3}{|c|}{$170,9 \pm 1,86$} \\
\hline \multicolumn{2}{|c|}{ Indeks Massa Tubuh (IMT) $\left(\mathrm{kg} / \mathrm{m}^{2}\right)$} & \multicolumn{3}{|c|}{$21,43 \pm 1,40$} \\
\hline \multicolumn{5}{|c|}{ Tabel 2 Perbedaan kadar D-Dimer sebelum dan sesudah tes } \\
\hline Variabel & $\mathbf{n}$ & $\begin{array}{c}\text { Median (Minimum- } \\
\text { Maksimum) }\end{array}$ & $\mathbf{Z}$ & $\mathbf{P}$ \\
\hline D-Dimer Sebelum & 30 & $45(28-200)$ & & \\
\hline D-Dimer Sesudah & 30 & $85(57-262)$ & -4.7 & 0,000 \\
\hline
\end{tabular}

45 (28-200) dan sesudah tes adalah 85 (57-262). Dengan nilai Z - 4.7 dan p 0.000. Setelah dilaksanakan uji normalitas menggunakan uji Kolmogorov-Smirnov, dan hasilnya $\mathrm{p}<$ dari 0.05 , maka data dinyatakan tidak berdistribusi normal. Yang selanjutnya digunakan Wilcoxon Signed Rank Test dengan hasil p 0.000. Hal ini menunjukkan adanya perbedaan signifikan antara D-Dimer sebelum dan sesudah tes kesamaptaan.

\section{PEMBAHASAN}

D-dimer (atau D dimer) adalah produk degradasi fibrin (atau FDP), adalah sebuah fragmen protein kecil yang ada dalam darah setelah bekuan darah terdegradasi oleh proses fibrinolisis. Dinamakan demikian karena mengandung dua fragmen $\mathrm{D}$ dari protein fibrin yang disambung dengan tautan silang. Konsentrasi D-dimer dapat ditentukan dengan tes darah untuk membantu mendiagnosis thrombosis. Sejak diperkenalkan pada 1990-an, D-dimer telah menjadi tes penting yang dilakukan pada pasien dicurigai dengan gangguan trombotik. Sementara hasil negatif praktis menyingkirkan diagnosa trombosis, hasil positif dapat menunjukkan trombosis tetapi tidak mengesampingkan penyebab potensial lainnya. Oleh karena itu, penggunaan utamanya adalah untuk menyingkirkan penyakit thromboemboli dengan probabilitasnya rendah. Selain itu, juga digunakan dalam diagnosis gangguan darah yang dikenal sebagai Disseminated Intravascular Coagulation (DIC). ${ }^{13}$

Akftifitas fisik berat akan menyebabkan aktifasi dari platelet, koagulasi dan fibrinolisis. ${ }^{14}$ Katekolamin, vasopressin, pelepasan epinephrine, hipoglikemia, peningkatan thrombin, kerusakan vaskuler akibat stressor fisik dan kerusakan otot, yang kesemuanya ini dapat terjadi pada saat aktifitas berat akan melepaskan tissue plasmin activator (tPA) dari sel endotel dan sudah tentu akan menyebabkan meningkatnya konsentrasi D-Dimer. Karena proses fibrinolisis diawali dengan pelepasan tPA dari sel endotel. ${ }^{15}$

Hal ini serupa dengan penelitian yang dilaksanakan oleh Kupchak dkk tahun 2013 ditemukan peningkatan D-Dimer dari baseline dengan ratarata 371.00 (150.02-591.98) pada 16 orang pesepeda dalam sebuah event sepeda balap dengan umur rata-rata 44.6. Pada penelitian ini dapat disimpulkan bahwa latihan fisik yang berat dan dalam waktu yang lama dalam hal ini bersepeda sejauh $164 \mathrm{~km}$ meningkatkan aktivitas fibrinolysis pada seseorang yang terlatih. Hal ini juga didukung dengan suhu dan cuaca yang ekstrim saat melaksanakan kegiatan tersebut. ${ }^{16}$

Begitu juga dengan penelitian yang dilaksanakan oleh Parker dkk tahun 2012 ditemukan peningkatan 
D-Dimer dengan rata-rata $245.00(0.00-490.00)$ pada 23 orang pelari marathon dengan umur ratarata 42 tahun. ${ }^{17}$

Di sisi lain penelitian yang dilaksanakan oleh Kathleen M dkk tahun 2011 ditemukan peningkatan signifikan pada D-Dimer dengan rata-rata $44 \pm 14$ sebelum latihan dan $55 \pm 15$ setelah latihan. Pada penelitian ini juga memperlihatkan meningkatnya aktivitas tPA yang merupakan precursor aktivitas fibrinolysis. Hal ini dapat disimpulkan bahwa intensitas latihan meningkatkan aktivitas tPA yang kemudian nanti juga meningkatkan aktivitas fibrinolitik. ${ }^{18}$

Pada penelitian yang dilaksanakan oleh Papadaki dkk 1998, juga disimpulkan bahwa semakin tinggi kerusakan pembuluh darah, menginduksi pelepasan tPA yang lebih tinggi. ${ }^{19}$

Dampak positif latihan pada kardiovaskular telah dijelaskan dengan baik. Namun, olahraga berat juga telah terbukti menyebabkan gangguan penting dalam kimia darah. D-Dimer sebagai produk degradasi enzimatik utama fibrin secara luas digunakan sebagai biomarker dengan tinggi nilai prediksi negatif pada pasien dengan dugaan PE, DVT, dan sindrom aorta akut. Pengerahan tenaga fisik menyebabkan aktivasi trombosit, koagulasi, dan fibrinolisis. Fibrinolisis dapat terjadi akibat pelepasan tissue plasminogen activator (tPA). Katekolamin, vasopresin, atau pelepasan epinefrin, hipoglikemia, peningkatan trombin, stres pembuluh darah, dan cedera otot, yang dapat terjadi selama aktivitas fisik, dapat melepaskan tPA dari pembuluh darah sel endotel dan menyebabkan peningkatan konsentrasi D-dimer. ${ }^{19}$

Keterbatasan penelitian ini adalah sampel 30 orang, homogenisitas yaitu sama-sama sehat, nutrisi, dan umur, keterbatasan lain adalah tidak adanya peralatan untuk mengukur kekuatan aerobik dan anaerobik peserta, dengan mengukur denyut jantung dan pengukuran laktat dikarenakan perlunya personil investigasi tambahan dan pengukuran langsung melalui intravena. Tes kesamaptaan yang dilakukan murni saat akan dilaksanakan penilaian periodik oleh bagian Jasmani Militer. Selanjutnya dalam menegakkan apakah terjadi VTE pada individu tersebut, harus dilakukan pemeriksaan lainnya seperti USG Dopler yang tidak dilakukan dalam penelitian ini.

\section{SIMPULAN}

Peningkatan D-Dimer pada subjek penelitian ini merupakan petunjuk bahwa terjadi proses peningkatan koagulasi darah yang dimana akan meningkatkan proses fibrinolisis. Dan pada penelitian ini menunjukkan bahwa bekuan darah dapat terjadi pada individu yang sehat dan sering melaksanakan aktivitas berat.

Berdasarkan hasil penelitian ini dapat disarankan untuk melakukan penelitian selanjutnya dengan melihat individu yang mempunyai aktifitas berat dan memiliki keluhan yang mengarahkan diagnosa kepada VTE, serta dilaksanakan skoring Wells dan pemeriksaan USG Dopler untuk membuktikan kecurigaan adanya VTE. Dan diperlukannya pemeriksaan D-Dimer serta USG Dopler pada saat pemeriksaan berkala prajurit yang dilaksanakan sebelum dilaksanakan tes kesamaptaan. Terutama pada anggota prajurit yang umurnya lebih dari 40 tahun.

\section{ETIKA PENELITIAN}

Penelitian ini telah mendapat persetujuan etik oleh komisi etik Fakultas Kedokteran, Universitas Sumatera Utara/RSUP H. Adam Malik, Medan, Indonesia.

\section{KONFLIK KEPENTINGAN}

Tidak terdapat konflik kepentingan dalam penulisan laporan penelitian ini.

\section{PENDANAAN}

Penelitian ini di dukung oleh PT. Setia Anugrah Medika.

\section{KONTRIBUSI PENULIS}

Semua penulis memiliki kontribusi yang sama dalam penulisan akhir laporan hasil penelitian.

\section{DAFTAR PUSTAKA}

1. Rooney KD, Schilling UM. Point-of-care testing in the overcrowded emergency department can it make a difference? Crit Care. 2014;18:1-7.

2. White R. The epidemiology of venous thromboembolism. Circulation. 2003;107:1-5.

3. ISTH Steering Committee for World Thrombosis Day. Thrombosis: a major contributor to global disease burden. J Thromb Haemost. 2014; 12: 1580-90.

4. JCS Guidelines. Guidelines for the diagnosis, treatment and prevention of pulmonary thromboembolism and deep vein thrombosis. Circ J. 2011;75: 1258-81.

5. Sudrajat Y. Kajian tes kesegaran jasmani "A" bagi personel kategori usia 50 tahun ke atas. Dispenad. 2014.

6. Kevin SK. The effect of exercise on D-dimer levels. Military Medicine. 2014;179:225.

7. Kupchak BR, Volk BM, Kunces LJ, Kraemer WJ, Hoffman MD, Phinney SD, Volek JS. Alterations in coagulatory and fibrinolytic systems following an ultra-marathon. Eur J Appl Physiol. 2013;113:2705-12.

8. Hui SK, Mast A. D-dimer: a non-invasive test for patients with suspected DVT. Clin Lab News. 2009. 
9. Wells PS, Anderson DR, Rodger M, Forgie M, Keron C, Dreyer J, et al. Evaluation of d-dimer in the diagnosis of suspected deep-vein thrombosis. N Engl J Med. 2003. 349:1227-35.

10. Stralen KJ, Le Cessie S, Rosendaal FR, Doggen CJ. Regular sports activities decrease the risk of venous thrombosis. J Thromb Haemost. 2007; 5:2186-92.

11. Posthuma JJ, Meijden PE, Cate HT, Spronk HM. Shortand long-term exercise induced alterations in haemostasis: a review of the literature. Blood Rev. 2015;2:171-8.

12. Bergeron MF, Nindl BC, Deuster PA. Consortium for health and military performance and american college of sports medicine consensus paper on extreme conditioning programs in military personnel. Curr Sports Med Rep. 2011;10:383-9.

13. Adam SS, Key NS, Greenberg CS. D-dimer antigen: current concepts and future prospects. Blood. 2013;113:2878-87

14. Sand KL, Flatebo T, Andersen MB, Maghazachi AA. Effects of exercise on leukocytosis and blood hemostasis in 800 healthy young females and males. World J Exp Med. 2013;3:11-20.

15. Womack CJ, Nagelkirk PR, Coughlin AM. Exerciseinduced changes in coagulation and fibrinolysis in healthy populations and patients with cardiovascular disease. Sports Med. 2003;33:795-807.
16. Kupchak BR, Volk BM, Kunces LJ, Kraemer WJ, Hoffman MD, Phinney SD, et al. Alterations in coagulatory and fibrinolytic systems following an ultramarathon. Eur J Appl Physiol. 2013;113:2705-12.

17. Parker BA, Augeri AL, Capizzi JA, Ballard KD, Kupchak BR, Volek JS, et al. Effect of marathon run and air travel on pre- and post-run soluble d-dimer, microparticle procoagulant activity, and p-selectin levels. Am J Cardiol 2012; 109:1521-5.

18. Kathleen M, Thomas H. Blood coagulation and fibrinolysis in healthy, untrained subjects: effects of different exercise intensities controlled by individual anaerobic threshold. Eur J Appl Physiol. 2011;111:253-60.

19. Papadaki M, Ruef J, Nguyen KT, Li F, Patterson C, Eskin SG, et al Differential regulation of protease activated receptor-1 and tissue plasminogen activator expression by shear stress in vascular smooth muscle cells. Circ Res. $1998 ; 83: 1027-34$.

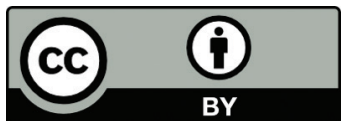

This work is licensed under a Creative Commons Attribution 